\title{
Effect of Fertilizer Additions on Plant Communities and Soil Properties in a Temperate Grassland Steppe
}

\author{
Feng He ${ }^{1}$, Zongyong Tong ${ }^{1}$, Lixue Wang ${ }^{2}$, Guiliang Zheng ${ }^{3}$, Xianglin Li ${ }^{1 *}$ \\ 'Institute of Animal Science, Chinese Academy of Agricultural Sciences, Beijing, P.R. China \\ ${ }^{2}$ Tianjin Animal Science and Veterinary Research Institute, Tianjin, P.R. China \\ ${ }^{3}$ Tianjin Forage and Feed Extension Station, Tianjin, P.R. China
}

Received: 8 July 2017

Accepted: 27 September 2017

\begin{abstract}
Temperate grassland steppe is an important natural ecosystem in the world, which is being degraded under the combined pressure of climate change and human over-utilization. Our objective was to determine the effect of inorganic and organic fertilizer addition and determine the appropriate fertilizer resource and additional rate for temperate grassland restoration. The treatments consisted of an inorganic and organic fertilizer, each with three additional rates. The effect of fertilizer addition on aboveground biomass, community structure, soil properties, and $\mathrm{N}$ balance were examined using a 2-year in situ controlled trial at Guyuan Grassland Station, Hebei Province, China. The results showed that inorganic fertilizer treatments increased the aboveground biomass, and decreased diversity and evenness of the plant community. Organic fertilizer treatments increased soil total carbon and the carbon-to-nitrogen ratio, but did not significantly change the aboveground biomass and soil available nutrition during the 2-year experiment. The $\mathrm{N}$ quantity of plant harvest output is approximate to that of fertilizer addition input in inorganic fertilizer treatment with $75 \mathrm{~kg} \mathrm{hm}^{-2}$ urea and $45 \mathrm{~kg} \mathrm{hm}^{-2}$ diammonium phosphate. The study demonstrated that using fertilizer addition to restore temperature grassland steppe requires a comprehensive evaluation of the diverse services functions of the present and future.
\end{abstract}

Keywords: fertilizer, aboveground biomass, community structure, soil properties, temperate grassland steppe

\section{Introduction}

Temperate grassland steppe is an important natural ecosystem in the world, providing a diverse range of plant

*e-mail: 1x1@caas.cn and animal species and ecosystem services, including wildlife habitat, forage resource for livestock, and carbon sequestration [1]. Leymus chinensis (Trin.) Tzvel is a native, perennial, rhizomatous grass. Grasslands dominated by $L$. chinensis are the dominant vegetation type in eastern Eurasian temperate grasslands. This grassland type occupies an area of $3 \times 10^{5} \mathrm{hm}^{2}$ in Inner Mongolia. It is typically utilized as hay and supplied 
to animals in the winter, and it also plays a key role in environmental security to the nation [2-3]. However, $L$. chinensis steppe has been degrading under the combined pressure of climate change and human overutilization and has been subjected to unsustainable use and conflicting interests since the 1980s [4-7]. Today, the planet is warming under atmospheric $\mathrm{CO}_{2}$ concentration increases [8-9], resulting in abnormal hydrothermal distribution and in erratic precipitation in arid and semiarid grassland ecosystems [10]. This represents a major challenge to temperate grassland, and encourages researchers to conduct studies relating to the successful restoration of ecological environments.

Infertile soil is one of the major factors restricting temperate grassland steppe sustainable development caused by over-utilization and the lack of an effective nutritional feedback approach. Limiting nutrients will change some key ecosystem processes and services, including the nutritional cycle, carbon sequestration, and changes to plant and soil communities [11-14]. An increasing number of studies have focused on the effect of nutrition addition in grassland ecosystems [15-18]. The fact that fertilizer addition can directly increase productivity has long been recognized [19-20]. A temperate grassland ecosystem is unlike a crop field, and in addition to the productivity function to the livelihood of herds, ecosystem services are also important services for human life. There is currently little research on both grassland productivity and ecosystem services. Most of the current research has demonstrated that fertilizer addition can alter soil properties, soil nitrogen cycling, and the stocks of soil carbon [21-23], which can result in a decline in species and functional group diversity [2426]. In addition, aboveground biomass (AGB) changes are accompanied by changes in soil microbial processes [27-31], which is closely related to soil fertility. However, fertilizer addition can also cause environmental problems such as nutrient leaching, groundwater contamination, eutrophication, and soil acidification [17]. Although fertilization is a regular practice on crop fields, there has not been effective guidance on its appropriate use in temperate grassland due to a lack of reliable experimental data to support it.

Some previous studies have identified the effect of $\mathrm{N}$ addition on grassland, especially on the effect of simulate atmospheric $\mathrm{N}$ deposition [32-37]. However, little research has demonstrated the effect of fertilizer addition, especially the effect when $\mathrm{N}$ and $\mathrm{P}$ were added simultaneously, on both productivity and ecosystem services. Therefore, our objective was to demonstrate the effect of fertilizer addition on plant community and soil properties, search the effective methods to promote vegetation growth and soil fertility, and realize sustainable development in a temperate grassland steppe.

\section{Experimental}

\section{Site Description}

The study was conducted from 2014 to 2015 at Guyuan Station $\left(41.77^{\circ} \mathrm{N}, 115.67^{\circ} \mathrm{E}, 1,400 \mathrm{~m}\right.$ a.s.1.), located at the southern edge of the Inner Mongolian Plateau in Hebei Province, northern China. This region

Table 1. Dominant plant species, life forms, photosynthetic pathways, and life history traits.

\begin{tabular}{|c|c|c|c|}
\hline Species & Life form & Photosynthetic pathway & Life history traits \\
\hline Leymus chinensis & Grass & $\mathrm{C} 3$ & Perennial \\
\hline Cleistogenes squarrosa & Grass & $\mathrm{C} 4$ & Perennial \\
\hline Artemisia frigida & Forb & $\mathrm{C} 3$ & Perennial \\
\hline Stipa krylovii & Grass & $\mathrm{C} 3$ & Perennial \\
\hline Agropyron cristatum & Grass & $\mathrm{C} 3$ & Perennial \\
\hline Heteropappus altaicus & Forb & $\mathrm{C} 3$ & Perennial \\
\hline Iris ensata & Forb & $\mathrm{C} 3$ & Perennial \\
\hline Phlomis tuberosa & Forb & $\mathrm{C} 3$ & Perennial \\
\hline Ixeris sonchifolia & Forb & $\mathrm{C} 3$ & Perennial \\
\hline Koeleria cristata & grass & $\mathrm{C} 3$ & Perennial \\
\hline Medicago sativa & Legume & $\mathrm{C} 3$ & Perennial \\
\hline Melissitus ruthenica & Legume & $\mathrm{C} 3$ & Perennial \\
\hline Potentilla anserine & Forb & $\mathrm{C} 3$ & Perennial \\
\hline Chenopodium glaucum & Forb & $\mathrm{C} 3$ & Annual \\
\hline Saussurea amara & Forb & $\mathrm{C} 3$ & Perennial \\
\hline Thalictrum petaloideum & Forb & $\mathrm{C} 3$ & Perennial \\
\hline
\end{tabular}


has a semiarid continental climate with mean annual precipitation of $400 \mathrm{~mm}$, primarily distributed between May and September. The mean annual temperature was $2.5^{\circ} \mathrm{C}$, the mean minimum temperature in the coldest month (January) was $-17.0^{\circ} \mathrm{C}$, and the mean maximum temperature in the hottest month (July) was $18.9^{\circ} \mathrm{C}$ (1995-2013). The growing season is approximately 100 days, from May to September. The major soil type is sandy loam dark chestnut soil (Calcic-orthic Aridisol in the U.S. classification system) [38], and is slightly alkaline ( $\mathrm{pH}$ 7.6). The experiment was conducted within a fenced, permanent 10-ha research paddock of a typical temperate grassland dominated by Leymus chinensis (Trin.) Tzvelev. Additional species included Stipa krylovii Roshev. (a tall perennial bunchgrass), Cleistogenes squarrosa (Trin.) Keng (a short perennial bunchgrass), and Artemisia frigida Willd (a short shrub) (Table 1). The nomenclature used is according to the international plant names index (IPNI 2017) [39].

\section{Experimental Design}

The treatments consisted of two different types of fertilizer, inorganic and organic, each with three additional rates. This factorial experiment was arranged in a randomized complete block design and replicated three times. The plot size was $3 \times 5 \mathrm{~m}\left(15 \mathrm{~m}^{2}\right)$ with $100 \mathrm{~cm}$ spacing between plots. Urea $(46 \% \mathrm{~N})$ and diammonium phosphate (DAP, $18 \% \mathrm{~N}$ and $46 \% \mathrm{P}_{2} \mathrm{O}_{5}$ ) was used as the source of $\mathrm{N}$ and $\mathrm{P}$ for inorganic fertilizer treatment. Organic fertilizer came from the Xin Xing manure company of Hebei Province, China $\left(3 \% \mathrm{~N}, 1.5 \% \mathrm{P}_{2} \mathrm{O}_{5}\right.$, $45 \%$ organic matter; Table 2). All the fertilizer addition was broadcast in the spring annually during 2014 to 2015.

\section{Data Collection}

Precipitation and air temperature were recorded at the Guyuan Ranch meteorological station located $30 \mathrm{~km}$ from the experimental site.

The AGB and plant community characteristics were measured at the peak of AGB on 13 August 2014 and 18 August 2015. All species were harvested with scissors within a $1 \times 1 \mathrm{~m}$ quadrat in each plot, oven-dried to a constant mass at $70^{\circ} \mathrm{C}$ for $48 \mathrm{~h}$, weighed, and ground for $\mathrm{N}$ concentration. Total $\mathrm{N}$ in plants was measured by elemental analyzer (vario ELIII, Elementar, Germany). A $0.5 \times 0.5 \mathrm{~m}$ quadrat with 100 sub-grids $(0.05 \times 0.05 \mathrm{~m})$ was used to measure the coverage of each species, with three replicates per plot. We determined the relative coverage of each (percentage cover). The individual numbers of each species and the plant community in the frame were counted. We determined the ShannonWiener index $\left(H^{\prime}\right)$, species richness (S), and Pielou evenness index $\left(J^{\prime}\right)$ for each plot. The Shannon-Wiener index $\left(H^{\prime}\right)$ calculated as $H^{\prime}=-\sum p i \ln (p i)$, where $p i$ is the proportional number of species $i$, and $\mathrm{S}$ is the species richness in the community. The Pielou evenness index was calculated as $J^{\prime}=H^{\prime} / \ln (\mathrm{S})$.

Three soil cores (5 $\mathrm{cm}$ diameter and $10 \mathrm{~cm}$ depth) were collected from each plot on 13 August 2014 and 18 August 2015. Each fresh soil core was sieved through $2 \mathrm{~mm}$ mesh and separated into two parts. One was used for soil moisture (oven dried at $105^{\circ} \mathrm{C}$ for $48 \mathrm{~h}$ ) and soil $\mathrm{pH}$ analysis. The other was used to estimate soil available $\mathrm{N}$ (AN, the sum of extractable soil ammonium $\left(\mathrm{NH}_{4}^{+}-\mathrm{N}\right)$ and nitrate $\left(\mathrm{NO}_{3}^{-}-\mathrm{N}\right)$ concentrations), soil available P (AP), soil total C (STC), soil total N (TN), and soil $\mathrm{C} / \mathrm{N}$ ratio. Soil $\mathrm{pH}$ value was determined in a $1: 2.5$ soil-water suspension at $25^{\circ} \mathrm{C}$ using a $\mathrm{pH}$ meter (FE20 from FiveEasy, Mettler, Toledo). $\mathrm{NH}_{4}^{+}-\mathrm{N}$ and $\mathrm{NO}_{3}^{-}-\mathrm{N}$ were extracted by $2 \mathrm{M} \mathrm{KCl}$ and determined with a flow injection autoanalyzer (FIAstar 5000 Analyzer, Foss Tecator, Denmark). Extractable $\mathrm{NH}_{4}^{+}-\mathrm{N}$ and $\mathrm{NO}_{3}^{-}-\mathrm{N}$ concentrations were converted to dry mass basis using soil moisture data. Soil available $\mathrm{P}$ was extracted by $0.5 \mathrm{M} \mathrm{NaHCO}$ solutions and determined with a continuous flow analyzer (Seal AutoAnalyzer 3, Seal, Germany), and STC and TN were measured by an elemental analyzer (vario ELIII, Elementar, Germany).

The $\mathrm{N}$ balance is $\mathrm{N}$ addition minus plant $\mathrm{N}$ output by harvest on each treatment in both 2014 and 2015.

\section{Data Analysis}

We examined the effects of fertilizer using the fertilizer addition treatment as sources of variance using the analysis of variance (ANOVA) model of SPSS

Table 2. Details of the fertilizer treatments in the Leymus chinensis steppe experiment.

\begin{tabular}{|c|c|c|c|c|}
\hline \multirow{2}{*}{ Treatment } & \multirow{2}{*}{ Detail } & \multicolumn{3}{|c|}{ Total nutrient addition $\left(\mathrm{kg} \mathrm{hm}^{-2} \mathrm{y}^{-1}\right)$} \\
\cline { 2 - 4 } & & $\mathrm{N}$ & $\mathrm{P}_{2} \mathrm{O}_{5}$ & Organic matter \\
\hline $\mathrm{CK}$ & No fertilizer applied & - & - & - \\
\hline $\mathrm{C} 1$ & $75 \mathrm{~kg} \mathrm{hm}^{-2}$ urea, $45 \mathrm{~kg} \mathrm{hm}^{-2} \mathrm{DAP}$ & 42.6 & 20.7 & - \\
\hline $\mathrm{C} 2$ & $150 \mathrm{~g} \mathrm{hm}^{-2}$ urea, $90 \mathrm{~kg} \mathrm{hm}^{-2} \mathrm{DAP}$ & 85.2 & 41.4 & - \\
\hline $\mathrm{C} 3$ & $225 \mathrm{~g} \mathrm{hm}^{-2}$ urea, $135 \mathrm{~kg} \mathrm{hm}^{-2} \mathrm{DAP}$ & 127.8 & 62.1 & - \\
\hline M1 & $1,400 \mathrm{~kg}$ organic fertilizer & 42 & 21 & 630 \\
\hline M2 & $2,800 \mathrm{~kg}$ organic fertilizer & 84 & 42 & 1,260 \\
\hline M3 & $4,200 \mathrm{~kg}$ organic fertilizer & 126 & 63 & 1,890 \\
\hline
\end{tabular}


software (version 19.0, SPSS Inc., Chicago, Illinois, USA, 2004). One-way ANOVA with least significant difference (LSD) multiple range tests was used to test the statistical significance in the mean values of the treatments. Statistical significances of all tests were set at $p<0.05$. Results from the statistical analyses of the data were graphed using Microsoft Excel software (version 2010, Microsoft, Seattle, Washington, USA, 2010).

\section{Results}

\section{Precipitation and Air Temperature}

Precipitation and air temperatures varied over the 2 years of the study. April mean temperature was $8.2^{\circ} \mathrm{C}$ in 2014 and only $5.7^{\circ} \mathrm{C}$ in 2015 . November precipitation was $43.3 \mathrm{~mm}$ in 2015 and only $1.3 \mathrm{~mm}$ in 2014 (Fig. 1). During the growing season from May through August, the amounts and distributions of precipitation and air temperatures were similar between the 2 years. The average air temperatures of growing season were 16.1 and $15.6^{\circ} \mathrm{C}$ in 2014 and 2015 , respectively, and precipitation was 250 and $228 \mathrm{~mm}$ in 2014 and 2015, respectively. Compared with the 1995-2013 average, both 2014 and 2015 had a higher monthly temperature in January and lower monthly precipitation in August (Fig. 1).

\section{Effect of Fertilization on Aboveground Biomass}

The AGB was 2.47 and $2.51 \mathrm{Mg} \mathrm{hm}^{-2}$ in $\mathrm{C} 2$ and $\mathrm{C} 3$ in 2014, respectively, both of which were significantly greater than that of M1, M2, and M3 (1.52, 1.75, and
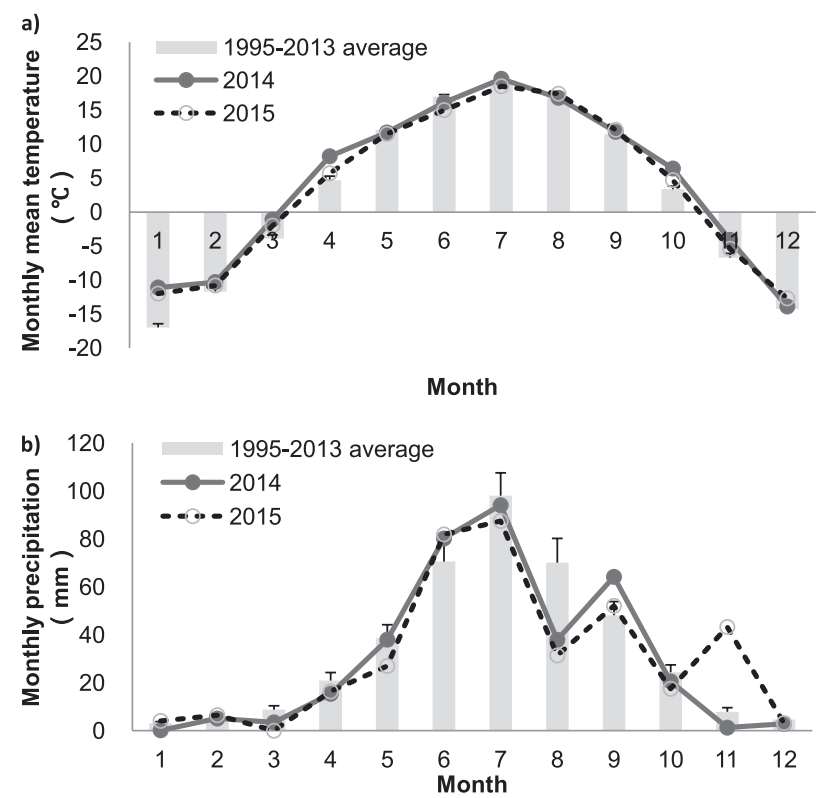

Fig 1. Monthly average temperature a) and total monthly precipitation b) in the experimental field 2014-2015; grey bars indicate the regional monthly averages (mean+SE) 1995-2013.

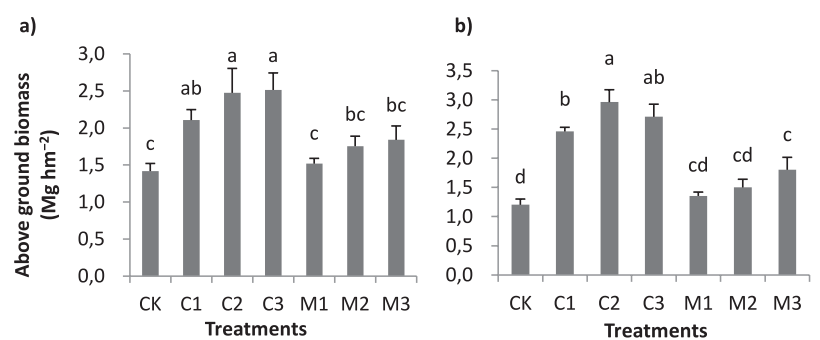

Fig. 2. Effect of fertilizer addition on aboveground biomass; for each panel, bars not labeled with the same letter indicate significantly different values at $p<0.05$ (based on LSD tests): a) effect of fertilizer addition in 2014 and b) in 2015.

$\left.1.84 \mathrm{Mg} \mathrm{hm}^{-2} ; \quad p<0.05\right)$. There were no significant differences among $\mathrm{CK}$ and organic fertilizer treatment (M1, M2, and M3) for AGB in 2014 (Fig. 2a). In 2015, AGB was 2.46, 2.96, and $2.71 \mathrm{Mg} \mathrm{hm}^{-2}$ in $\mathrm{C} 1, \mathrm{C} 2$, and $\mathrm{C} 3$, greater than that of M1, M2, and M3 (1.36, 1.50, and
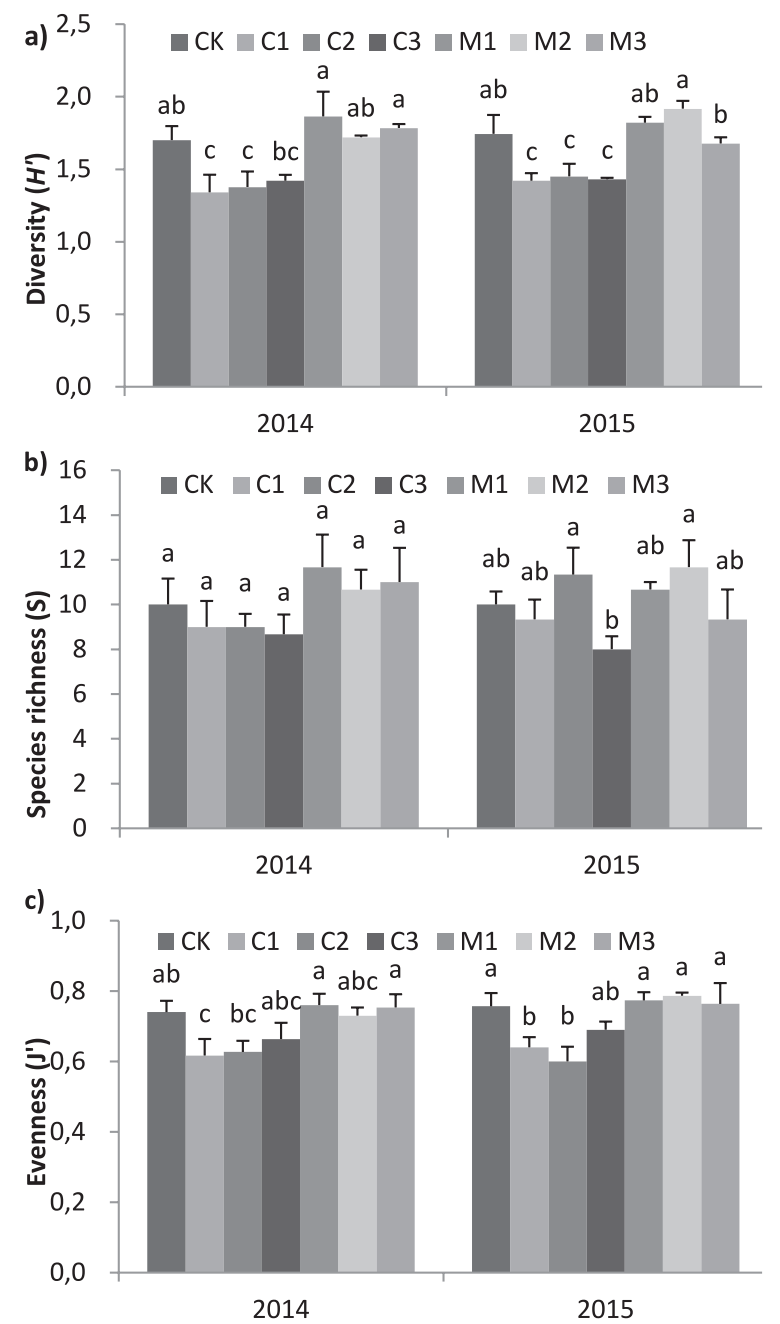

Fig. 3. Effect of fertilizer addition on Shannon-Wiener index, species richness, and Pielou evenness index; for each panel, bars not labeled with the same letter indicate significantly different values at $p<0.05$ (based on LSD tests): a) effect of fertilizer addition on $H^{\prime}$, b) on $\mathrm{S}$, and c) on $J^{\prime}$. 
$\left.1.80 \mathrm{Mg} \mathrm{hm}^{-2} ; p<0.05\right)$. There were no significant differences among $\mathrm{CK}$ and organic fertilizer treatments (M1 and M2) for AGB in 2015 (Fig. 2b).

\section{Effect of Fertilization on the Community Structure}

The Shannon-Wiener index $\left(H^{\prime}\right)$ was $1.86,1.72$, and 1.78 in M1, M2, and M3 in 2014, respectively, all of which were greater than that of $\mathrm{C} 1, \mathrm{C} 2$, and $\mathrm{C} 3(1.34,1.38$, and $1.42 ; p<0.05)$. There were no significant differences among CK and organic fertilizer treatments (M1, M2, and M3) for $H^{\prime}$ in 2014. In 2015, $H^{\prime}$ was $1.82,1.92$, and 1.68 in M1, M2, and M3, respectively, significantly greater than those of $\mathrm{C} 1, \mathrm{C} 2$, and $\mathrm{C} 3(1.42,1.45$, and 1.43; $p<0.05)$. There were no significant differences among CK and organic fertilizer treatments (M1 and M2) for $H^{\text {, }}$ in 2015 (Fig. 3a).

There were no significant differences among treatments on species richness (S) in 2014. In 2015, S was 8.0 in $\mathrm{C} 3$, lower than that of $\mathrm{C} 2$ and $\mathrm{M} 2$ (11.33 and 11.67; $p<0.05)$, and there were no significant differences among the other treatments (Fig. 3b).

The Pielou evenness index $\left(J^{\prime}\right)$ was 0.62 and 0.63 in $\mathrm{C} 1$ and $\mathrm{C} 2$ in 2014, respectively, and both were lower than that of M1 and M3 (0.76 and $0.75 ; p<0.05)$. There were no significant differences among $\mathrm{CK}$, organic fertilizer treatment (M1, M2, and M3) and C3 for $J$ ' in 2014. In 2015, $J$ ' was 0.64 and 0.60 in $\mathrm{C} 1$ and $\mathrm{C} 2$, both significantly lower than that of M1, M2, and M3 $(0.77,0.79$ and $0.76 ; p<0.05)$. There were no significant differences among CK, organic fertilizer treatments (M1, M2, and M3), and C3 for $J$ ' in 2015 (Fig. 3c).

\section{Effect of Fertilization on Soil Nutrition}

Soil AN was 54.82, 63.53, and $66.94 \mathrm{mg} \mathrm{kg}^{-1}$ in $\mathrm{C} 1$, $\mathrm{C} 2$, and $\mathrm{C} 3$, respectively, greater than that of $\mathrm{M} 1, \mathrm{M} 2$, $\mathrm{M} 3$, and CK $\left(38.39,41.27,38.38\right.$, and $37.71 \mathrm{mg} \mathrm{kg}^{-1}$; $p<0.05)$ in 2015. There were no significant differences among CK and organic fertilizer treatment (M1, M2, and M3) for AN (Fig. 4a).

Soil AP was 8.13, 6.60, and $6.77 \mathrm{mg} \mathrm{kg}^{-1}$ in $\mathrm{C} 1, \mathrm{C} 2$, and $\mathrm{C} 3$, respectively, significantly greater than that of M1, M2, and CK $\left(4.66,4.73\right.$ and $\left.3.99 \mathrm{mg} \mathrm{kg}^{-1} ; p<0.05\right)$. There were no significant differences among organic fertilizer treatments (M1, M2, and M3) for AP (Fig. 4b).

STC was $38.62,36.02$, and $48.67 \mathrm{~g} \mathrm{~kg}^{-1}$ in M1, M2, and $\mathrm{M} 3$, respectively, significantly greater than that of $\mathrm{C} 1, \mathrm{C} 2, \mathrm{C} 3$, and CK $\left(26.39,29.20,23.36\right.$, and $27.20 \mathrm{~g} \mathrm{~kg}^{-1}$; $p<0.05$ ) (Fig. 4c).

Soil C/N ratios were $14.84,14.28$, and 17.88 in M1, $\mathrm{M} 2$, and $\mathrm{M} 3$, respectively, significantly greater than those of C1, C2, C3, and CK $(10.28,11.24,9.07$, and 10.37; $p<0.05$ ) (Fig. 5d). There were no significant differences among CK and inorganic fertilizer treatments $(\mathrm{C} 1, \mathrm{C} 2$, and C3; Fig. 4d), and no significant differences among all the treatments on soil TN (Fig. 4e) and pH (Fig. 4f) in 2015.
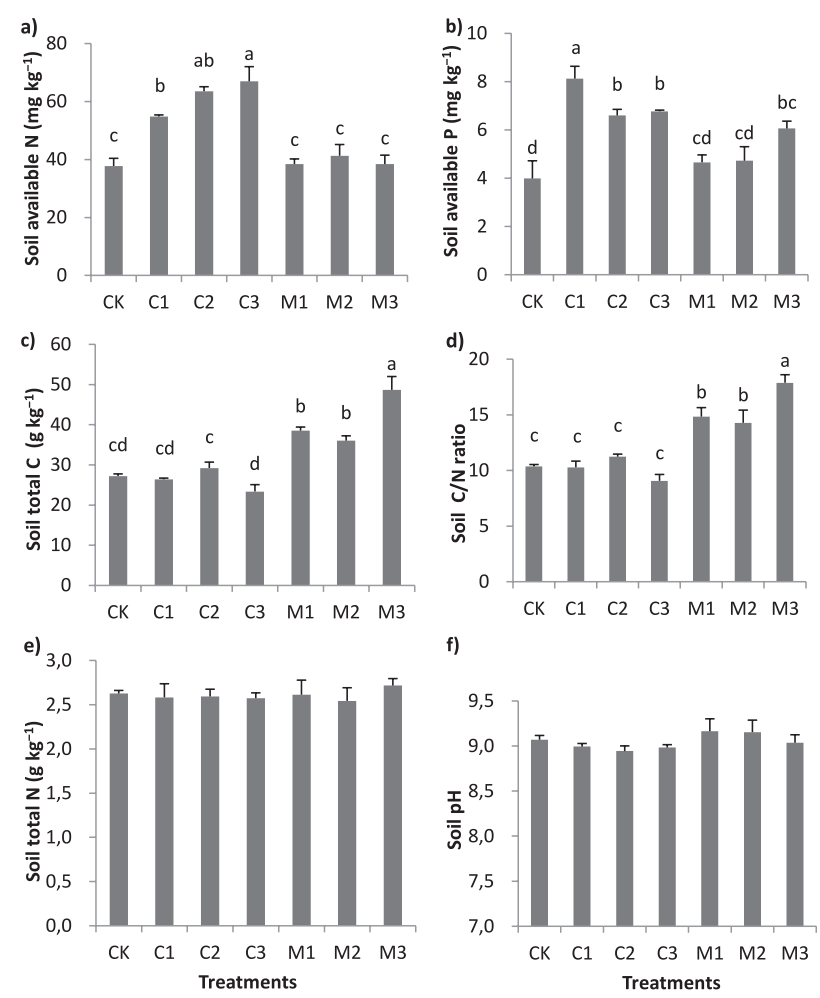

f)

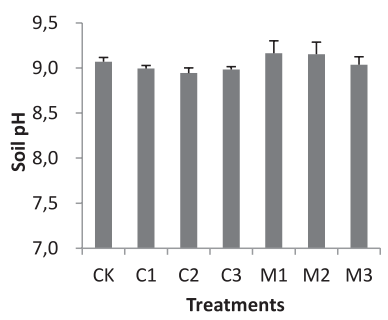

Fig. 4. Effect of fertilizer addition on soil available N, soil available $\mathrm{P}$, soil total $\mathrm{C}$, soil $\mathrm{C} / \mathrm{N}$ ratio, soil total nitrogen, and $\mathrm{pH}$; for each panel, bars not labeled with the same letter indicate significantly different values at $p<0.05$ (based on LSD tests): a) effect of fertilizer addition on AN, b) on AP, c) on STC, d) on $\mathrm{C} / \mathrm{N}, \mathrm{e}$ ) on $\mathrm{TN}$, and $\mathrm{f}$ ) on $\mathrm{pH}$.

\section{Plant N Concentration}

Plant N concentration (PNC) was $2.40 \%$ of $\mathrm{C} 3$ in 2014, significantly greater than that of organic fertilizer treatments M1, M2, and M3 $(1.55,1.49$, and $1.36 \%$, respectively; $p<0.05)$. There were no significant differences among $\mathrm{CK}$ and organic fertilizer treatments (M1, M2, and M3) for PNC in 2014 (Fig. 5a). In 2015, $\mathrm{PNC}$ was $2.52 \%$ in $\mathrm{C} 3$, greater than that of M1, M2, and M3 (1.63, 1.54, and 1.35\%, respectively; $p<0.05$ ). As in 2014, there were no significant differences among CK
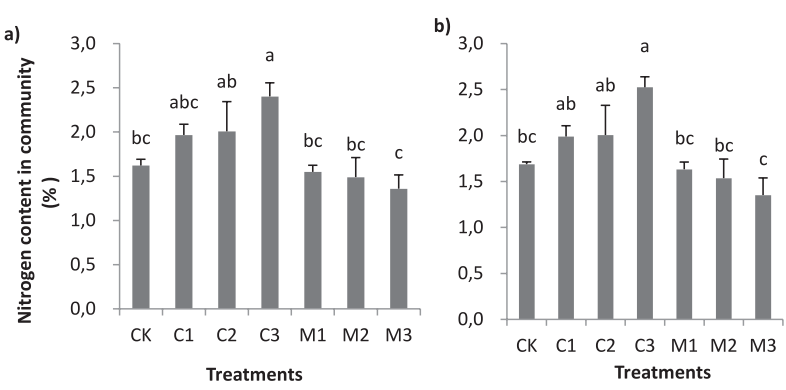

Fig. 5. Effect of fertilizer addition on nitrogen content in community; for each panel, bars not labeled with the same letter indicate significantly different values at $p<0.05$ (based on LSD tests): a) effect of fertilizer addition in 2014 and b) in 2015. 
Table 3. N balance of each of fertilizer treatment during 2014-2015. For each column, value (mean \pm SE) not labeled with the same letter indicates significantly different values at $p<0.05$ (based on LSD tests).

\begin{tabular}{|c|c|c|c|c|}
\hline \multirow{2}{*}{ Treatment } & \multirow{2}{*}{ N addition $\left(\mathrm{hm}^{-2} \mathrm{y}^{-1}\right)$} & \multicolumn{2}{|c|}{ Harvest N output $\left(\mathrm{kg} \mathrm{hm}^{-2}\right)$} & \multirow{2}{*}{ N Balance $\left(\mathrm{kg} \mathrm{hm}^{-2}\right)$} \\
\cline { 3 - 4 } & & 2014 & 2015 & -43.37 \\
\hline CK & 0 & $23.14 \pm 3.12 \mathrm{c}$ & $20.23 \pm 2.31 \mathrm{c}$ & -4.54 \\
\hline C1 & 42.6 & $41.09 \pm 1.87 \mathrm{~b}$ & $48.64 \pm 0.63 \mathrm{~b}$ & 65.41 \\
\hline C2 & 85.2 & $46.58 \pm 0.82 \mathrm{~b}$ & $58.42 \pm 9.14 \mathrm{ab}$ & 127.59 \\
\hline C3 & 127.8 & $59.60 \pm 3.55 \mathrm{a}$ & $68.41 \pm 6.96 \mathrm{a}$ & 38.15 \\
\hline M1 & 42 & $23.67 \pm 2.75 \mathrm{c}$ & $22.19 \pm 2.14 \mathrm{c}$ & 119.72 \\
\hline M2 & 84 & $25.76 \pm 3.76 \mathrm{c}$ & $22.52 \pm 2.82 \mathrm{c}$ & 204.10 \\
\hline M3 & 126 & $24.13 \pm 3.47 \mathrm{c}$ & $23.77 \pm 1.46 \mathrm{c}$ & \\
\hline
\end{tabular}

and organic fertilizer treatment (M1, M2, and M3) for PNC in 2015 (Fig. 5b).

\section{N Balance}

Harvest $\mathrm{N}$ output was $59.60 \mathrm{~kg} \mathrm{hm}^{-2}$ of $\mathrm{C} 3$ in 2014, greater than that of $\mathrm{C} 1$ and $\mathrm{C} 2$ (41.09 and $46.58 \mathrm{~kg} \mathrm{hm}^{-2}$, respectively; $p<0.05$ ), and greater than that of CK and organic fertilizer treatments $(p<0.05)$. The same findings were shown for 2015. The highest value of $\mathrm{N}$ balance was $204.10 \mathrm{~kg} \mathrm{hm}^{-2}$ in M3, the lowest value of $\mathrm{N}$ balance was $-43.37 \mathrm{~kg} \mathrm{hm}^{-2}$ in CK during 2014 to 2015 (Table 3). $\mathrm{N}$ balance was $-4.54 \mathrm{~kg} \mathrm{hm}^{-2}$ of $\mathrm{C} 1$ treatment, of which $\mathrm{N}$ input is approximately that of harvest $\mathrm{N}$ output.

\section{Discussion}

\section{Effect of Fertilizer Addition on AGB and Community Structure}

Our results clearly show that fertilizer addition has led to marked differences on AGB and community structure between treatment plots in this temperature grassland (Fig 2-3). Soil AN and AP of CK was $37.71 \mathrm{mg} \mathrm{kg} \mathrm{kg}^{-1}$ and $3.99 \mathrm{mg} \mathrm{kg}^{-1}$, respectively, which demonstrates that the original soil is highly infertile. Therefore, the addition of inorganic fertilizer had a marked influence on biomass, which is in accordance with previous research [19-20]. The dominant species is $L$. chinensis, which is a poaceae plant that is very sensitive to $\mathrm{N}$ addition. However, the addition of more inorganic fertilizer did not enhance AGB, and there was no significant difference between inorganic fertilizer treatments in 2014. Compared with the $\mathrm{C} 2$ treatment, AGB declined in the $\mathrm{C} 3$ treatment in 2015. Previous studies have shown that $\mathrm{N}$ limitation is tightly coupled with water availability in semiarid grassland ecosystems $[10,25,32]$. The AGB responds more to added $\mathrm{N}$ in wet years than in dry years [17, 33-34]. The precipitation was $250.2 \mathrm{~mm}$ and $227.8 \mathrm{~mm}$ in 2014 and 2015, respectively. Lack of precipitation limited the fertilizer effect on biomass. Moreover, more inorganic fertilizer will cause physiological drought, which limits plant growth. Compared with inorganic fertilizer, organic fertilizer showed no marked influence on biomass; since the nutrition concentration was very low, soil AN and AP cannot increase over such a short period (Fig. 4).

Previous studies have shown that fertilizer addition also results in a declined in plant species diversity [23$24,26]$. In our study, there was no significant difference in the species number in 2014, and only maximum fertilizer C3 showed a significant difference in 2015. The Shannon-Wiener index decreased under inorganic fertilizer treatments, since the fertilizer increased poaceae species growth, producing an overshadowing effect on aboveground, repressing the growth of other species [40-41]. If fertilizer addition is used over the long term, it is likely to cause species losses from the community. The Pielou evenness index decreased with the Shannon-Wiener index since the species numbers did not significantly change over the 2-year experiment, except for the inorganic fertilizer treatment C3 in 2015 (Fig. 3).

\section{Effect of Fertilizer Addition on Soil Properties}

Fertilizer addition changed soil properties. Although the inorganic fertilizer can increase soil AN and AP quickly, but not significantly change STC and soil C/N ratio, organic fertilizer increases $\mathrm{STC}$ and $\mathrm{C} / \mathrm{N}$ ratio but not soil AN and AP (Figs 4a-d). This is because inorganic fertilizer has a higher nutrition concentration and the nutrition in the inorganic form, which is easily taken into solution in the soil and absorbed by plants. The organic fertilizer provides nutrients in organic form, most of which must be transformed into an inorganic form before plant absorption and utilization. Moreover, organic fertilizer contains a large amount of organic matter, resulting in soil carbon content and $\mathrm{C} / \mathrm{N}$ ratio increase which can promote soil microbial processes and soil enzyme activity [27-31], enhancing soil fertility. Both inorganic fertilizer and organic fertilizer cannot 
significantly change the soil total $\mathrm{N}$ over the course of 2 years (Fig. 4e). In our study, we also found that soil $\mathrm{pH}$ of inorganic fertilizer treatment showed a declining tendency compared with that of organic fertilizer (Fig. 4f), which supports some previous research [17, 25], organic fertilizer can increase the soil buffering capacity to resist soil acidification due to the presence of bivalent cations ( $\mathrm{Ca}^{2+}$ and $\mathrm{Mg}^{2+}$ in manure), and/or the oxidation of organic anions that will consume $\mathrm{H}^{+}$ions during manure decomposition [42].

\section{Effect of Fertilizer Addition on $\mathrm{N}$ Balance}

Maintenance of the $\mathrm{N}$ balance is very important in ecosystem sustainable management. Although a lack of soil $\mathrm{N}$ nutrition will limit plant productivity, adding it could threaten the natural environment, causing problems such as nutrient leaching, groundwater contamination, and eutrophication [17, 43-45]. The CK treatment carried out $43.37 \mathrm{~N} \mathrm{~kg} \mathrm{hm}^{-2}$ from the soil by harvest removal, which resulted in AN decrease and limited plant growth. The $\mathrm{C} 1$ treatment carried out $89.73 \mathrm{~N} \mathrm{~kg} \mathrm{hm}^{-2}$, the $\mathrm{N}$ balance was $-4.54 \mathrm{~N} \mathrm{~kg} \mathrm{hm}^{-2}$, which also increased soil AN reach to $54.82 \mathrm{mg} \mathrm{kg}^{-1}$. The inorganic treatments $\mathrm{C} 2$ and $\mathrm{C} 3$ released 65.41 and $127.59 \mathrm{~N} \mathrm{~kg} \mathrm{hm}^{-2}$ to the environment, respectively, which represents a potential environmental risk. In addition, the C2 and C3 treatments did not significantly increase the AGB in our study. Although organic treatment releases more $\mathrm{N}$ to the soil, it also provides plentiful organic matter to the soil, which increases the STC and $\mathrm{C} / \mathrm{N}$ ratio, benefiting soil fertility.

Our research findings therefore present a choice. Inorganic fertilizer may be applied at $42.6 \mathrm{~N} \mathrm{~kg} \mathrm{hm}^{-2}$ to temperate grassland when local people need to increase the AGB in order to supply more hay feed to the animals in the winter and guarantee the livelihood of herds. However, we do not recommend this fertilizer approach continuously, as it will decrease community diversity and evenness. In addition, $\mathrm{N}$ limitation is tightly coupled with water availability in semiarid grassland ecosystems and precipitation distribution is erratic; therefore, inorganic fertilizer addition may represent a considerable environmental risk.

\section{Conclusions}

Inorganic fertilizer addition increased AGB, but decreased diversity and evenness of the temperate grassland community. Organic fertilizer addition increased STC and $\mathrm{C} / \mathrm{N}$ ratio, but had little influence on AGB and soil available nutrition over the 2 years of our experiment. Our research demonstrated that using fertilizer addition to restore temperature grassland steppe need to comprehensively evaluate the diverse services functions.

\section{Acknowledgements}

This study was financially supported by the National Natural Science Foundation of China (31302015), the Special Fund for Agro-scientific Research in the Public Interest (201303060), and the China Forage and Grass Research System (CARS-34). We thank Qin Yan, Quan Guoling, Xu Hongyu, Wan Xiufu, Li Yue, and Ma Zhao for their assistance with field data collection. We also thank the anonymous reviewers and editors for their comments, which improved our manuscript.

\section{References}

1. WHITE S.R., CARLYLE C.N., FRASER L.H., CAHILL J.F. Climate change experiments in temperate grasslands: synthesis and future directions. Ecol. Lett. 8 (4), 484, 2012.

2. LI L.H., WANG Q.B., BAI Y.F., ZHOU G.S., XING X.R. Soil respiration of a Leymus chinensis grassland stand in the Xilin river basin as affected by over-grazing and climate. Acta Phytoecologica Sinica. 24 (6), 680, 2000.

3. WU Z. Vegetation of China. Science Press, Beijing, China. 1980 [In Chinese].

4. ZHANG X.S., TANG H.P., DONG X.B., BO L., HUANG Y.M., GONG J.R. The dilemma of steppe and its transformation in China. Chin. Sci. B. 61 (2), 165, 2016.

5. FANG J.Y., BAI Y.F., LI L.H., JIANG G.M., HUANG J.H., HUANG Z.Y., ZHANG W.H., GAO S.Q. Scientific basis and practical ways for sustainable development of China's pasture regions. Chin. Sci. Bull. 61 (2), 155, 2016.

6. KEMP D.R., HAN G.D., HOU X.Y., MICHALK D.L., HOU F.J., WU J.P., ZHANG Y.J. Innovative grassland management systems for environmental and livelihood benefits. PNAS. 110 (21), 8369, 2013.

7. HAN X.G., LI L.H. Mechanisms for maintaining Inner Mongolian grassland ecosystems. China Agricultural University Press, Beijing, 2012 [In Chinese].

8. SEVIK H., CETIN M., BELKAYALI N. Effects of Forests on Amounts of CO2: Case Study of Kastamonu and Ilgaz Mountain National Parks. Pol. J. Environ. Stud. 24 (1), 253, 2015.

9. CETIN M., SEVIK H., ISINKARALAR K. Changes in the particulate matter and $\mathrm{CO}_{2}$ concentrations based on the time and weather conditions: the case of Kastamonu. Oxid. Commun. 40 (1-II), 477, 2017.

10. SALA O.E., GHERARDI L.A., REICHMANN L., JOBBAGY E., PETERS D. Legacies of precipitation fluctuations on primary production: theory and data synthesis. Phi. T. Roy. B. 367 (1606), 3135, 2012.

11. KNORR M., FREY S.D., CURTIS P.S. Nitrogen additions and litter decomposition: A meta-analysis. Ecology. 86 (12), 3252, 2005 .

12. ELSER J.J., BRACKEN M.E.S., CLELAND E.E., GRUNER D.S., HARPOLE W.S., HILLEBRAND H., NGAI J.T., SEABLOOM E.W., SHURIN B.J., SMITH J.E. Global analysis of nitrogen and phosphorus limitation of primary producers in freshwater, marine and terrestrial ecosystems. Ecol. Lett. 10 (12), 1135, 2007.

13. LEBAUER D.S., TRESEDER K.K. Nitrogen limitation of net primary productivity in terrestrial ecosystems is globally distributed. Ecology. 89 (2), 371, 2008. PMID: 18409427. 
14. CHEN D., LAN Z., HU S., BAI Y. Effects of nitrogen enrichment on belowground communities in grassland: Relative role of soil nitrogen availability vs. soil acidification. Soil Biol. B. 89, 99, 2015.

15. ZHAN S., WANG Y., ZHU Z., LI W., BAI Y. Nitrogen enrichment alters plant N: P stoichiometry and intensifies phosphorus limitation in a steppe ecosystem. Envir. Exp. B. 134, 21, 2017.

16. YING J.Y., LI X.X., WANG N.N., LAN Z.C., HE J.Z., BAI Y.F. Contrasting effects of nitrogen forms and soil $\mathrm{pH}$ on ammonia oxidizing microorganisms and their responses to long-term nitrogen fertilization in a typical steppe ecosystem. Soil Biol. B. 107, 10, 2017.

17. KIDD J., MANNING P., SIMKIN J., PEACOCK S., STOCKDALE E. Impacts of 120 years of fertilizer addition on a temperate grassland ecosystem. Plos One. 12 (3), e0174632, 2017. https://doi.org/10.1371/journal. pone. 0174632

18. LIU N., KAN H.M., YANG G.W., ZHANG Y.J. Changes in plant,soil and microbes in typical steppe from simulated grazing: explaining potential change in soil carbon. Ecol. Monogr. 85 (2), 269, 2015.

19. GOUGH L., OSENBERG C.W., GROSS K.L., COLLINS S.L. Fertilization effects on species density and primary productivity in herbaceous plant communities. Oikos. 89 (3), 428, 2000.

20. LEE M., MANNING P., RIST J., POWER S.A., MARSH C. A global comparison of grassland biomass responses to $\mathrm{CO}_{2}$ and nitrogen enrichment. Phi. T. Roy. B. 365(1549), 2047, 2010.

21. MACK M.C., SCHUUR E.A., BRET-HARTE M.S., SHAVER G.R., CHAPIN F.S. Ecosystem carbon storage in arctic tundra reduced by long-term nutrient fertilization. Nature. 431 (7007), 440, 2004.

22. JASTROW J.D., AMONETTE J.E., BAILEY V.L. Mechanisms controlling soil carbon turnover and their potential application for enhancing carbon sequestration. Clim Change. 80, 5, 2007.

23. GROENIGEN V.K.J., SIX J., HUNGATE B.A., GRAAFF D.M.A., BREEMEN V.N, KESSEL V.C. Element interactions limit soil carbon storage. PNAS. 103 (17), 6571, 2006.

24. SUDING K.N., COLLINS S.L., GOUGH L., CLARK C., CLELAND E.E., GROSS K.L., MILCHUNAS D.G., STEVEN P. Functional-and abundancebased mechanisms explain diversity loss due to N fertilization. PNAS. 102 (12), 4387, 2005.

25. BAI Y., WU J., CLARK C.M., NAEEM S., PAN Q., HUANG J., ZHANG L., HAN X. Tradeoffs and thresholds in the effects of nitrogen addition on biodiversity and ecosystem functioning: evidence from inner Mongolia Grasslands. Gl. Change B. 16 (1), 358, 2010.

26. STEVENS C.J., THOMPSON K., GRIME J.P., LONG C.J., GOWING D.J.G. Contribution of acidification and eutrophication to declines in species richness of calcifuge grasslands along a gradient of atmospheric nitrogen deposition. Funct. Ecol. 24 (2), 478. 2010.

27. RAMIREZ K.S., CRAINE J.M., FIERER N. Consistent effects of nitrogen amendments on soil microbial communities and processes across biomes. Gl. Change B. 18 (6), 1918, 2012.

28. CHENG W. Rhizosphere priming effect: its functional relationships with microbial turnover, evapotranspiration, and C-N budgets. Soil Biol. B. 41 (9), 1795, 2009.

29. RAJANIEMI T.K., ALLISON V.J. Abiotic conditions and plant cover differentially affect microbial biomass and community composition on dune gradients. Soil Biol. B. 41 (1), 102, 2009.

30. FIERER N., LAUBER C.L., RAMIREZ K.S., ZANEVELD J., BRADFORD M.A., KNIGHT R. Comparative metagenomic, phylogenetic and physiological analyses of soil microbial communities across nitrogen gradients. Isme J. 6 (5), 1007, 2012

31. CLEGG C.D. Impact of cattle grazing and inorganic fertiliser additions to managed grasslands on the microbial community composition of soils. Appl. Soil E. 31 (1), 73, 2006.

32. LAN Z.C., BAI Y.F. Testing mechanisms of N-enrichmentinduced species loss in a semiarid Inner Mongolia grassland: critical thresholds and implications for long-term ecosystem responses. Phi. T. Roy. B. 367 (1606), 3125, 2012.

33. HOOPER D.U., JOHNSON L. Nitrogen limitation in dryland ecosystems: responses to geographical and temporal variation in precipitation. Biogeochemistry. 46 (1), 247, 1999.

34. LAN Z.C., JENERETTE G.D., ZHAN S.X., LI W.H., ZHENG S.X., BAI Y.F. Testing the scaling effects and mechanisms of $\mathrm{N}$-induced biodiversity loss: evidence from a decade-long grassland experiment. J. Ecology. 103 (3), 750, 2015.

35. CHEN D.M., LAN Z.C., HU S.J., BAI Y.F. Effects of nitrogen enrichment on belowground communities in grassland: Relative role of soil nitrogen availability vs. soil acidification. Soil Biol. B. 89, 99, 2015.

36. ZHANG Y.G., YANG S., FU M.M., CAI J.P., ZHANG Y.Y., WANG R.Z., Xu Z.W., BAI Y.F., JIANG Y. Sheep manure application increases soil exchangeable base cations in a semi-arid steppe of Inner Mongolia. Journal of Arid Land. 7 (3), 361, 2015

37. BAI Y.F., WU J.G., CLARK C.M., NAEEM S., PAN Q.M., HUANG J.H., ZHANG L.X., HAN X.G. Tradeoffs and thresholds in the effects of nitrogen addition on biodiversity and ecosystem functioning: evidence from Inner Mongolia Grasslands. Gl. Change B. 16 (1), 358, 2010.

38. WANG J., CAI W. Studies on genesis, types and characteristics of the soils in the Xilin River Basin, Inner Mongolia. Research Grassland Ecosystem. 3, 23, 1988 [In Chinese].

39. IPNI. International Plant Names Index. Available online: www.ipni.org/ipni/plantnamesearchpage.do (accessed on 5 July 2017).

40. HAUTIER Y., NIKLAUS P.A., HECTOR A. Competition for light causes plant biodiversity loss after eutrophication. Science. 324 (5927), 636, 2009.

41. HARPOLEA W.S., TILMAN D. Grassland species loss resulting from reduced niche dimension. Nature. 446 (7137), 791, 2007.

42. HAYNES R.J., MOKOLOBATE M.S. Amelioration of Al toxicity and $\mathrm{P}$ deficiency in acid soils by additions of organic residues: a critical review of the phenomenon and the mechanisms involved. Nutr. Cycl. A. 59 (1), 47, 2001.

43. WU L., QI T., ZHANG J. Spatiotemporal variations of adsorbed nonpoint source nitrogen pollution in a highly erodible Loess Plateau watershed. Pol. J. Environ. Stud. 26 (3), 1343, 2017.

44. ZHENG S.Z., XIAO M.H., MIAO Z.M. Nitrogen losses in paddy field drainage modified by different water level regulations. Pol. J. Environ. Stud. 26 (3), 1393, 2017.

45. ZHU J., KANG F.F., CHEN J., CHENG X.Q., HAN H.R. Effect of nitrogen addition on soil respiration in a larch plantation. Pol. J. Environ. Stud. 26 (3), 1403, 2017. 